\title{
Genetics of Leaf Rust Resistance in Brambling Wheat
}

J. X. Zhang, Department of Agronomy and Plant Genetics, University of Minnesota, St. Paul 55108; R. P. Singh, International Maize and Wheat Improvement Center (CIMMYT), Apdo Postal 6-641, 06600, Mexico D.F., Mexico; J. A. Kolmer, USDA-ARS Cereal Disease Laboratory, Department of Plant Pathology, University of Minnesota, St. Paul 55108; J. Huerta-Espino, Campo Experimental Valle de Mexico, INIFAP, Apdo. Postal 10, Chapingo, 56230 Edo de Mexico, Mexico; Y. Jin, USDA-ARS Cereal Disease Laboratory, Department of Plant Pathology, University of Minnesota, St. Paul 55108; and J. A. Anderson, Department of Agronomy and Plant Genetics, University of Minnesota, St. Paul 55108

\begin{abstract}
Zhang, J. X., Singh, R. P., Kolmer, J. A., Huerta-Espino, J., Jin, Y., and Anderson, J. A. 2008. Genetics of leaf rust resistance in Brambling wheat. Plant Dis. 92:1111-1118.

The CIMMYT-developed spring wheat 'Brambling' has a high level of adult-plant resistance (APR) to leaf rust caused by Puccinia triticina. Our objectives were to determine the genetic basis of resistance in seedlings and adult plants and the magnitude of genotype $\times$ environment effects on the expression of APR. Brambling was crossed with spring wheat 'Jupateco 73S' that is highly susceptible to current predominant $P$. triticina races in Mexico and the United States. The $\mathrm{F}_{1}, \mathrm{~F}_{2: 3}, \mathrm{~F}_{4: 5}, \mathrm{~F}_{4: 6}$, and $\mathrm{F}_{5: 7}$ recombinant inbred lines (RILs) were evaluated under artificial field epidemics in Mexico and St. Paul, MN. The RILs also were tested with five races of $P$. triticina in greenhouse seedling experiments. A DNA marker was used to postulate the presence of slow-rusting gene Lr34 in the RILs. $F_{1}$ data suggested strong dominant effect of the APR genes in Brambling. The proportion of homozygous susceptible lines in each generation indicated the presence of three effective resistance genes in adult plants of Brambling in tests in Mexico and three or four genes in tests in St. Paul. The RILs segregated for seedling genes $L r 14 a$ and $L r 23$ and adult-plant slow-rusting gene Lr34 derived from Brambling and Lr17a from Jupateco 73S. Gene Lr23 conditioned APR to P. triticina races present in the St. Paul nursery and accounted for the additional effective gene at this location. Expression of APR was influenced by the environment in the RILs, even though Brambling displayed a consistent response, indicating that stability of APR can be achieved by combinations of slow-rusting resistance genes.
\end{abstract}

Additional keywords: durable resistance, temperature sensitivity

Leaf or brown rust, caused by the fungus Puccinia triticina Eriks., is the most common disease of wheat (Triticum aestivum L.) in North America (3). Although more than 50 leaf rust resistance genes have been catalogued (21), most of those genes confer seedling resistance, are race specific, and vulnerable to selection for new virulent races. Some leaf rust resistance genes express resistance optimally in adult plants and are referred to as adultplant resistance (APR) genes. Genes $\operatorname{Lr} 12$ and $L r 13$ are race-specific APR genes that have been rendered largely ineffective due to selection of virulent rust races $(11,12)$.

Corresponding author: J. A. Anderson

E-mail: ander319@umn.edu

Current address of J. X. Zhang: Pioneer Hi-Bred Int., DuPont Agriculture and Nutrition, 19456 State Hwy 22, Mankato, MN 56001

Accepted for publication 14 March 2008.

\section{doi:10.1094/PDIS-92-7-1111}

This article is in the public domain and not copyrightable. It may be freely reprinted with customary crediting of the source. The American Phytopathological Society, 2008.
While almost all seedling resistance genes and many APR genes condition a hypersensitive response (HR), some APR genes condition a response of fewer and smaller uredinia compared with susceptible check genotypes, which has been referred to as slow rusting (2) or partial (25) resistance.

Two slow-rusting resistance genes, $\operatorname{Lr} 34$ and $L r 46$, condition nonrace-specific APR and have provided durable leaf rust resistance $(4,19,27,36)$. It was estimated that approximately a dozen slow-rusting genes were present among cultivars developed at the International Maize and Wheat Improvement Center (CIMMYT) (34). Combinations of three to four such slow-rusting genes resulted in resistance that can approach immunity (30). Currently however, only Lr34 and Lr46 have been well characterized.

Genetic characterization of additional APR genes is essential for parental selection for breeders to alter selection strategies and introduce genetic diversity in breeding for durable leaf rust resistance. Moreover, the addition of CIMMYT APR into the U.S. wheat breeding germplasm could result in more durable leaf rust resistance in U.S. wheat cultivars. Comparing the performance of genotypes with APR in CIMMYT and U.S. wheat environments can determine the extent of environmental effects on the expression of APR.

Brambling is a wheat breeding line developed at CIMMYT and is highly resistant to leaf rust in Mexico and the United States. On the basis of the pedigree and observation of leaf rust resistance, it might carry other APR genes in addition to Lr34 and/or Lr46. Our objectives were to: i) identify race-specific resistance genes in the cross of Jupateco $73 \mathrm{~S} \times$ Brambling by evaluating recombinant inbred lines (RILs) in the seedling stage with $P$. triticina races; ii) determine the genetic basis of slowrusting APR present in Brambling through field trials in Mexico and St. Paul, MN; and iii) study the magnitude of genotype $\times$ environment effects of APR in the Mexico and St. Paul environments.

\section{MATERIALS AND METHODS}

Plant materials. Brambling, a spring wheat line developed by CIMMYT with the pedigree Weaver/Ocoroni 86//Borlaug 95 (cross number and selection history: CGSS96B00145T-099B-021Y-099M-19YOB-1B) has stable, near immune levels of APR to leaf rust. It was crossed as the male parent with the CIMMYT-derived spring wheat line 'Jupateco 73S' that is highly susceptible to the $P$. triticina races predominant in North America. Jupateco $73 \mathrm{~S}$ was a reselection from the Mexican spring wheat cultivar Jupateco 73 for leaf rust susceptibility (29). The $F_{1}$ and generations of $\mathrm{F}_{2: 3}, \mathrm{~F}_{4: 5}, \mathrm{~F}_{4: 6}$, and $\mathrm{F}_{5: 7}$ RILs developed by the single-seed descent method were used in the field studies. The $\mathrm{F}_{5: 7}$ RILs were used in the seedling greenhouse experiments.

Seedling studies. Seven isolates of $P$. triticina were used in various seedling studies (Table 1). These isolates were collected from wheat in the United States and Canada and were designated for virulence phenotype following the three letter code system of Long and Kolmer (17), with an additional fourth letter that described the high or low infection type (IT) to Thatcher wheat lines with genes $\operatorname{LrB}, \operatorname{Lr} 10, \operatorname{Lr} 14 a$, and Lrl8. Races BBBD (isolate name: Race 1), THBJ (99 ND 588-1), MHDS (03 OH 237), SBDG (Race 9), and PBLR (MI 
91-2) were used in testing the $\mathrm{F}_{5: 7}$ RILs of the Jupateco 73S/Brambling cross. These five isolates were selected on the basis of their low IT to at least one of the parents in the cross and low IT to specific leaf rust resistance genes common in CIMMYT germplasm. Approximately 14 seeds from each of the $135 \mathrm{~F}_{5: 7}$ RILs, Brambling, Jupateco $73 \mathrm{~S}$, the leaf rust susceptible wheat Thatcher, and 17 near-isogenic lines of Thatcher wheat with single resistance genes Lr1, Lr2a, Lr2c, Lr3, Lr3ka, Lr9, Lr10, Lr11, Lr14a, Lr16, Lr17a, Lr18, Lr23, Lr24, Lr26, Lr30, and LrB were tested with each isolate.

Seeds were planted in $3.5-\mathrm{cm}^{2}$ plastic pots in vermiculite as described by Oelke and Kolmer (23). Plants were grown in a greenhouse at 18 to $22^{\circ} \mathrm{C}$ with $16 \mathrm{~h}$ of supplemental light. Approximately 8 days after planting, when the first leaf was fully expanded, the seedlings were inoculated by spraying urediniospores of the individual isolate suspended in Soltrol 170 oil. After air drying for $30 \mathrm{~min}$, the inoculated seedling plants were incubated in a mist chamber for 16 to $24 \mathrm{~h}$ at $18^{\circ} \mathrm{C}$ and $100 \%$ relative humidity and then moved back to the greenhouse for further incubation.

On the basis of the greenhouse seedling experiments, we postulated that $L r 23$ was present in Brambling. In our greenhouse studies, the Thatcher Lr23 line had ITs of $; 2^{+} 3$ to isolates BBBD and THBJ. Most of the RILs had the same IT to isolates BBBD and THBJ. However, nine RILs differed for IT to isolates BBBD and THBJ. The seedling ITs of those lines were intermediate to high. The uncertainty and disagreement between BBBD and THBJ in those RILs could be due to temperature sensitivity of $L r 23$ since this gene is more effective at higher temperatures (5). To validate the postulation of $L r 23$ in Brambling, the nine RILs with different ITs to isolates BBBD and/or THBJ, along with Brambling, Jupateco 73S, Thatcher, Thatcher near-isogenic lines with $L r 17 a$, $L r 14 a$, and $L r 23$ were evaluated for reaction to isolates BBBD and THBJ. After incubation in the dew chamber, the plants were placed in growth cabinets at 20 or $25^{\circ} \mathrm{C}$ with a mixture of florescent and incandescent light with a $16-\mathrm{h}$ day. Planting, inoculation, and dew chamber incubation procedures of the growth cabinet study were the same as the greenhouse experiment. Infection types were recorded 12 days after inoculation in the greenhouse and $20^{\circ} \mathrm{C}$ growth cabinet tests and 8 days after inoculation in the $25^{\circ} \mathrm{C}$ growth cabinet experiment. The ITs were classified as 0 to 4 following Long and Kolmer (17) in which $0=$ no uredinia or hypersensitive flecks, ; = no uredinia but hypersensitive necrotic or chlorotic flecks, $1=$ small uredinia surrounded by distinct necrosis, 2 $=$ small to medium uredinia surrounded by necrosis or chlorosis, and $3=$ moderate size uredinia without chlorosis. Designations of "+" or " - " indicate larger than normal uredinia and smaller uredinia, respectively. ITs of 0 to $2^{+}$were classified as low infection type and ITs of 3 to 4 were classified as high. Infection type combining different numbers and/or symbols indicated that the infected leaf had uredinia of different sizes and were classified as low if ITs of 0 to $2^{+}$were present in the combination. The $\mathrm{F}_{5: 7}$ RILs with low ITs were classified as homozygous resistant, RILs with high ITs were classified as homozygous susceptible, and RILs segregating for high and low ITs were classified as segregating. The ratio of homozygous resistance, homozygous susceptible, and segregating RILs was used to determine the number of seedling resistance genes that were effective against each isolate. Probable genes in each RIL were postulated by comparing with the ITs of the Thatcher near-isogenic lines with individual leaf rust resistance genes.

Molecular marker for $\mathbf{L r 3 4}$. The sequence-tagged site DNA marker csLV34 (14) was used to screen for Lr34 in Brambling. This marker is 0.4 centimorgans (cM) distant from Lr34 and is diagnostic for $L r 34$ of wheat cultivars from different parts of the world (14). Jupateco 73S, Thatcher, and RL 6058 (Thatcher isoline for Lr34) were included as checks. DNA was extracted from leaf segments of five random plants of each check and $\mathrm{F}_{5: 7}$ line following Liu et al. (16). Polymerase chain reactions (PCR) were performed in $10-\mu l$ reactions containing 3- $\mu$ l of genomic DNA (30 to $45 \mathrm{ng}$ ). After an initial denaturing step for $3 \mathrm{~min}$ at $94^{\circ} \mathrm{C}, 35$ cycles were performed with $1 \mathrm{~min}$ at $94^{\circ} \mathrm{C}, 1 \mathrm{~min}$ at $58^{\circ} \mathrm{C}, 2 \mathrm{~min}$ at $72^{\circ} \mathrm{C}$, followed by a final extension step of $10 \mathrm{~min}$ at $72^{\circ} \mathrm{C}$. PCR products of $c s L V 34$ were run on polyacrylamide gels containing $32 \%(\mathrm{v} / \mathrm{v})$ formamide (15). The gels were visualized by silver staining (1).

Adult-plant field studies. Field evaluations were conducted at Ciudad Obregon, State of Sonora, Mexico; El Batan, State of Mexico, Mexico; and St. Paul, Minnesota during various crop seasons from 2003 to 2006. The crop season at Ciudad Obregon is from November to April, whereas at El Batan, the cycle runs from May to October and at St. Paul, from April to August.

Field plots at Ciudad Obregon and El Batan, Mexico, were established on $80 \mathrm{~cm}$ wide raised beds and consisted of two 1-m rows, $20 \mathrm{~cm}$ apart, on top of the beds with 0.5-m alleys. The field plots at St. Paul, MN consisted of single 2-m rows with 30 $\mathrm{cm}$ between plots and 2-m alleys. In the studies of the $\mathrm{F}_{2: 3}$ and $\mathrm{F}_{4: 5}, \mathrm{~F}_{4: 6}$, and $\mathrm{F}_{5: 7}$ RILs, each plot was planted with approximately 100 seeds.

In the 2002-2003 crop season, $F_{1}, 237$ $\mathrm{F}_{2: 3}$ lines, and $133 \mathrm{~F}_{4: 5}$ RILs were planted at Ciudad Obregon. Each generation was planted as different experiments. The $F_{1}$ was space sown in two plots with 20 seeds per plot. Brambling and Jupateco $73 \mathrm{~S}$ were planted in the beginning, middle, and end of the $\mathrm{F}_{2: 3}$ and $\mathrm{F}_{4: 5}$ lines as standard checks. In 2004, $\mathrm{F}_{4: 6}$ RILs were grown in Ciudad Obregon, Mexico and St. Paul, MN with one replication at each location. In Mexico and St. Paul, MN in 2005 and 2006, $137 \quad \mathrm{~F}_{5: 7}$ RILs were evaluated. In 2005, Mexican leaf rust evaluation was conducted at Ciudad Obregon, whereas the 2006 Mexican nursery was planted at El Batan. The $F_{1}$ to $F_{4}$ derived $\left(F_{4: 5}\right.$ and $\left.F_{4: 6}\right)$ generations were planted with one replication. Experimental design for $\mathrm{F}_{5: 7}$ RILs was a randomized complete block with two replications in each year and location

Table 1. Seedling infection types of 'Jupateco 73S', 'Brambling', and four 'Thatcher' near-isogenic lines for leaf rust resistance genes to races of Puccinia triticina used in greenhouse and growth chamber environments

\begin{tabular}{|c|c|c|c|c|c|c|c|c|c|c|c|}
\hline \multirow[b]{4}{*}{ Wheat lines } & \multicolumn{11}{|c|}{ Infection type $^{\mathrm{a}}$} \\
\hline & \multirow{2}{*}{\multicolumn{7}{|c|}{ Greenhouse isolates }} & \multicolumn{4}{|c|}{ Growth chamber isolates and temperatures } \\
\hline & & & & & & & & PPPD & BBRD & THRI & THBI \\
\hline & BBBD & THBJ & MHDS & SBDG & PBLR & MBDS & TLGF & $20^{\circ} \mathrm{C}$ & $25^{\circ} \mathrm{C}$ & $\mathbf{2 0}^{\circ} \mathrm{C}$ & $25^{\circ} \mathrm{C}$ \\
\hline Brambling & $; 123$ & $22^{+}$ & $; 1$ & 0 & $; 1^{-}$ & 3 & $; 2+3$ & 0 & 0 & $; 2^{+}$ & 0 \\
\hline Jupateco $73 \mathrm{~S}$ & 0 & 0 & $3^{+}$ & $3^{+}$ & 123 & $3^{+}$ & $; 1$ & 0 & 0 & 0 & 0 \\
\hline Thatcher & $33^{+}$ & 3 & $33^{+}$ & $33^{+}$ & 3 & $3^{+}$ & $33^{+}$ & 3 & $3^{+}$ & 3 & $3^{+}$ \\
\hline TcLr14a RL 6013 & $33^{+}$ & $3^{+}$ & $3^{+}$ & 0 & ;123 & $3^{+}$ & $3^{+}$ & $3^{+}$ & $3^{+}$ & 3 & 3 \\
\hline TcLr17a RL 6008 & $; 1$ & $; 2$ & $3^{+}$ & $3^{+}$ & ;12 & $3^{+}$ & $; 1$ & $0 ; 1^{-}$ & $00^{-}$ & 0 & $0 ; 1^{-}$ \\
\hline TcLr23 RL 6012 & $; 2+3$ & $; 2+3$ & 0 & $; 1^{-}$ & $33^{+}$ & $33^{+}$ & $2^{+} 3$ & $; 1$ & 0 & 0 & $0 ; 1^{-}$ \\
\hline TcLr34 RL 6058 & $3^{+}$ & $33^{+}$ & $3^{+}$ & $33^{+}$ & $\ldots{ }^{b}$ & $\ldots$ & $\ldots$ & 3 & 3 & 3 & 3 \\
\hline
\end{tabular}

${ }^{\mathrm{a}}$ Infection types follow Long and Kolmer (17).

b ... Indicates data not available. 
except one replication in the 2005 St. Paul field test.

Leaf rust epidemics in each environment (one environment $=$ one year and one location) were initiated by artificial inoculations of susceptible spreader rows. The Mexican locations were inoculated with the Mexican race MCJ/SP (28) that has avirulence/virulence formula of $\operatorname{Lr} 2 a, 2 b$, $2 c, 3 k a, 9,16,19,21,24,25,28,29,30$, $32,33,34 / 1,3,3 b g, 10,11,12,13,14 a$, $14 b, 15,17,18,20,22 b, 23,26$, and $27+31$. Seedlings of Jupateco $73 \mathrm{~S}$ and Brambling had high ITs to this race. Approximately 4 and 6 weeks after planting at El Batan and Obregon, respectively, the spreader rows of the highly susceptible cultivar Morocco, planted as hills on one side of the plots in the middle of the pathway and around the experimental block, were sprayed with urediniospores suspended in a mineral oil once a day for 3 days. The St. Paul location was spray inoculated with isolates THBJ, MCDS (520), and MBRJ (16-2B) when the earliest plants in the spreader row (leaf rust susceptible wheat cultivars LMPG-6, Morocco, and Thatcher) reached heading stage. Races THBJ and MCDS were common in the recent leaf rust population (11) and MBRJ was common in the 1990s (18).

Leaf rust severity was recorded on the basis of the modified Cobb scale (26) when all plants in the plots of susceptible parent Jupateco $73 \mathrm{~S}$ just reached $100 \%$ severity and the leaves had not yet senesced. The $F_{1}$ and $F_{2: 3}, F_{4: 5}, F_{4: 6}$, and $F_{5: 7}$ lines were assessed on the basis of the average rust severity on the flag leaves of 5 to 10 plants. Lines in various generations were grouped into two phenotypic categories for $\chi^{2}$ analyses: i) homozygous susceptible (lines with severity response similar to the susceptible parent, Jupateco 73S); and ii) others (lines homozygous for low to intermediate disease severities or segregating for low/intermediate and high severities).

The goodness of fit of the observed and expected phenotypic groups of the RILs was tested by $\chi^{2}$ analysis. Analysis of variance of the mean terminal leaf rust severity in the $\mathrm{F}_{5: 7}$ trials with two replications were conducted, treating each year and location combination as one environment. Pearson correlation coefficients of disease severity of the $\mathrm{F}_{5: 7}$ lines were estimated using the mean disease severity of each line in each environment. A Student's $t$-test was conducted between lines of different gene combinations using the means of each $\mathrm{F}_{5: 7}$ RIL in each environment.

\section{RESULTS}

Seedling leaf rust resistance genes in Brambling and Jupateco 73S. Jupateco 73S had low ITs 0 ; to 123 to isolates BBBD, THBJ, PBLR, TLGF and high IT of $3^{+}$to isolates MHDS, SBDG, and MBDS (Table 1). ITs displayed by Jupateco $73 \mathrm{~S}$ to BBBD and THBJ were not affected by temperature. The low and high IT pattern of Jupateco $73 \mathrm{~S}$ to the isolates were the same as the Thatcher line with Lr17a (RL6008), which indicated that $L r 17 a$ was likely present in Jupateco 73S. In greenhouse tests, Brambling had low ITs $0 ;$ to $; 2^{+} 3$ to all isolates tested in Table 1 , except for high IT to isolate MBDS (00 SD 520). Isolates BBBD, THBJ, MHDS, MBDS, and TLGF (00 SC 218) were virulent to the Thatcher line with $L r 14 a$ (RL6013). Isolates SBDG and PBLR were avirulent to the Thatcher line with Lr14a. Among the isolates tested, only PBLR and MBDS were virulent to the Thatcher line with Lr23 (RL6012). The ITs of Brambling to BBBD and THBJ were affected by temperature. In greenhouse tests, Brambling had IT ; 123 to isolate BBBD and $22^{+}$ to isolate THBJ. In the growth cabinet, Brambling had IT 0; to BBBD at 20 and $25^{\circ} \mathrm{C}$. Brambling had lower IT to THBJ at $25^{\circ} \mathrm{C}$ than at $20^{\circ} \mathrm{C}$. The Thatcher line with Lr23 also had lower IT in the growth cabinet at $25^{\circ} \mathrm{C}$ than at $20^{\circ} \mathrm{C}$ to isolate THBJ. On the basis of these results, Brambling was postulated to carry resistance genes Lr14a and Lr23.

In greenhouse tests with races BBBD and THBJ, the $F_{5: 7}$ RILs segregated for resistant, susceptible, and segregating lines in a ratio not significantly different from the 0.7178:0.2197:0.0625 ratio expected for $\mathrm{F}_{5: 7}$ with two independent dominant genes for a trait (Table 2). The $\mathrm{F}_{5: 7}$ RILs had the same resistant, susceptible, or segregating patterns to $\mathrm{BBBD}$ and $\mathrm{THBJ}$, which indicated that the same two genes controlled seedling resistance to these races. The Thatcher line with $L r 23$ had IT 0 ; to isolate MHDS. The $\mathrm{F}_{5: 7}$ RILs segregated to MHDS in a ratio not different from the expected 0.4688:0.4688:0.0625 ratio for $\mathrm{F}_{5: 7}$ for a single dominant trait that suggested that one gene in Brambling conditioned resistance to MHDS. Isolate SBDG had low ITs to Thatcher lines with Lr14a and Lr23 and the $\mathrm{F}_{5: 7}$ RILs segregated 88:29:14 for resistant, susceptible, and segregating families, which conformed to a $0.7178: 0.2197: 0.0625$ ratio expected for two genes in Brambling that conferred resistance to this isolate. To isolate PBLR, which had low ITs on LrI4a and LrI7a, the segregation ratio of $\mathrm{F}_{5: 7}$ RILs in resistant, susceptible, and segregating categories was in accordance with a 0.7178: 0.2197:0.0625 ratio, which suggested that two genes conditioned resistance to this isolate.

Table 3 lists a subset of lines that do not contain Lr34 based on lack of the diagnostic linked marker $c s L V 34$, but were postulated to have individual resistance genes or a combination of seedling resistance genes. RIL 117 was postulated to have Lr14a because it had high ITs to isolates BBBD, THBJ, and MHDS, but low ITs to SBDG and PBLR. RIL 128 was postulated to segregate for $L r 14 a$ because it had high ITs to isolates BBBD, THBJ, and MHDS and segregated for low, and high ITs to isolates SBDG and PBLR. The RILs 105, 119, and 144 were postulated to have $\operatorname{Lr} 17 a$ only because these lines had IT 0 ; to isolates BBBD, THBJ, and PBLR, and IT $33^{+}$to MHDS and SBDG. RIL 92 was postulated to have $L r 23$ because it had IT ;123 to isolate $\mathrm{BBBD}, \mathrm{IT} 2^{+} 3$ to THBJ, and 0 ; to isolates MHDS and SBDG and high IT to PBLR. RIL 14 was postulated to have $L r 14 a$ and $L r 17 a$ since it had IT 0; to isolates BBBD, THBJ, SBDG, PBLR and IT $33^{+}$to MHDS. RIL 57 and RIL 104 were postulated to have $L r 23$ and $L r 14 a$ because those lines had IT ; 123 to BBBD, IT $2^{+} 3$ to THBJ, and IT 0 ; to MHDS, SBDG, and PBLR. When Lr17a and Lr23 were postulated to be present, the line had low ITs to all five isolates in Table 3 . Restricted by the available isolates that were used, we could not postulate the presence or absence of Lrl4a in those lines, e.g., RIL 93 and RIL 113 in Table 3. The RILs

Table 2. Segregation of a DNA marker diagnostic for $L r 34$ and leaf rust resistance in greenhouse tests of seedling plants of $\mathrm{F}_{5: 7}$ recombinant inbred lines from the cross 'Jupateco 73S/Brambling'

\begin{tabular}{|c|c|c|c|c|c|c|c|}
\hline \multirow[b]{2}{*}{ Leaf rust races/molecular marker } & \multirow[b]{2}{*}{ Gene(s) detected } & \multicolumn{3}{|c|}{ No. of lines ${ }^{a}$} & \multirow[b]{2}{*}{ Expected ratio } & \multirow[b]{2}{*}{$\chi^{2}$ value } & \multirow[b]{2}{*}{$P$ value } \\
\hline & & Res. & Sus. & Seg. & & & \\
\hline $\operatorname{csLV} 34$ & Lr34 & 68 & 54 & 13 & 0.4688:0.4688:0.0625 & 4.20 & 0.12 \\
\hline BBBD & Lr17a, Lr23 & 87 & 34 & 11 & 0.7178:0.2197:0.0625 & 2.50 & 0.29 \\
\hline THBJ & Lr17a, Lr23 & 86 & 33 & 11 & $0.7178: 0.2197: 0.0625$ & 2.28 & 0.32 \\
\hline MHDS & Lr23 & 53 & 70 & 8 & $0.4688: 0.4688: 0.0625$ & 2.36 & 0.31 \\
\hline SBDG & Lr14a, Lr23 & 88 & 29 & 14 & 0.7178:0.2197:0.0625 & 4.45 & 0.10 \\
\hline PBLR & $\operatorname{Lr} 14 a, L r 17 a$ & 94 & 29 & 12 & $0.7178: 0.2197: 0.0625$ & 1.61 & 0.45 \\
\hline
\end{tabular}

${ }^{\mathrm{a}}$ Res. = homozygous for the resistance allele or resistant to the race; Sus. = homozygous for the alternative allele or susceptible to the race; and Seg. = segregating for resistance and alternative allele or resistant and susceptible plants. 
34, 82, and 106 had high ITs to all the isolates, which indicated these did not have any seedling resistance genes.

Lr34 genotyping. Marker csLV34 produced an allele of approximately $155 \mathrm{bp}$ in the Thatcher line with Lr34 and in Brambling and an alternative allele of approximately 250 bp in Thatcher and Jupateco $73 \mathrm{~S}$, which indicated that Brambling has the Lr34 APR gene. The $\mathrm{F}_{5: 7}$ lines segregated 68:54:13 for lines homozygous for the Lr34 associated allele, homozygous for the alternative allele, and segregating for the Lr34 and the alternative allele, respectively; these results fit the 0.4688:0.4688: 0.0625 expected ratio for a single locus (Table 2). Across the four environments, the field leaf rust severity of the 68 lines postulated to have Lr34 ranged from 1 to 70\%. Some RILs without the Lr34 gene were highly susceptible to leaf rust (leaf rust severity $=100 \%$ ) (Table 3 ). The lack of complete susceptibility of the RILs containing Lr34 marker allele indicated that csLV34 is diagnostic of Lr34 in the Jupateco 73S/Brambling cross, and recombination between $c s L V 34$ and Lr34 did not occur or it was a rare event in this population.

Field APR in Brambling. Brambling had rust severity and response of 0 to 1 MSS (moderately susceptible to susceptible) in all the environments except in 2006, St. Paul, where it was 10 MS. Jupateco
$73 \mathrm{~S}$ had $100 \mathrm{~S}$ (susceptible) severity and response in all environments except 50 to $70 \mathrm{~S}$ in 2006 St. Paul. The relatively lower rust severity for Jupateco $73 \mathrm{~S}$ and higher leaf rust severity for Brambling in $2006 \mathrm{St}$. Paul nursery was likely because of abnormally dry and hot weather immediately after planting until the first week of July. From May until early July in 2006 St. Paul, the dew point for most nights was lower than the night temperature, which indicated that moisture was probably not adequate for leaf rust infection. In early July, when the environment became conducive for leaf rust infection, Jupateco 73S had already reached the anthesis stage. Thus, the leaf rust severity of Jupateco $73 \mathrm{~S}$ in this environment was lower than normal. Generally, Brambling reached the anthesis stage 2 days later than Jupateco 73S. Reduced effectiveness of possible temperature-sensitive APR gene(s) in Brambling therefore could have resulted in higher levels of leaf rust in Brambling in the 2006 St. Paul nursery. The effect of drought and heat was also observed in the $\mathrm{F}_{5: 7}$ RILs in this environment. Disease severities of highly susceptible lines were lower in 2006 than in 2005 (Table 3), and lines with very low rust in 2005 , tended to have similar or higher disease than in 2006.

Analysis of variance for leaf rust severity of the $\mathrm{F}_{5: 7}$ RILs in Ciudad Obregon in
2005 and El Batan and St. Paul in 2006 revealed highly significant effects of RIL, environment, and RIL $\times$ environment interaction $(P<0.001)$. However, analysis of variance using only two environments indicated that RIL $\times$ environment effect was due to the difference between the St. Paul and Mexican locations. The RIL $\times$ environment interaction was significant when 2006 St. Paul and 2006 El Batan $(P$ $<0.001)$ or 2006 St. Paul and 2005 Obregon were analyzed $(P<0.001)$, but nonsignificant in analyzing El Batan and Obregon $(P=0.43)$. The significant difference between 2006 St. Paul and the Mexican environments is further supported by the moderate correlation coefficients of the means of rust severity of the RILs between 2006 St. Paul and 2006 El Batan $(r$ $=0.45, P<0.001$; Table 4) and 2006 St. Paul and 2005 Obregon $(r=0.45, P<$ $0.001)$ and very high correlation between 2005 Obregon and 2006 El Batan $(r=$ $0.99, P<0.001)$. The correlation coefficient of leaf rust severity between $2005 \mathrm{St}$ Paul and means of rust severity in the Mexican locations was higher $(r=0.63, P$ $<0.001$ ) than between 2006 St. Paul and the two Mexican locations. The correlation coefficient of leaf rust severity between 2005 St. Paul and mean of 2006 St. Paul nursery was high $(r=0.83, P<0.001)$.

There was a continuous distribution of leaf rust severity from 0 to $100 \%$ for lines

Table 3. Greenhouse seedling infection types and field leaf rust severities of 14 'Jupateco 73 S/Brambling' $F_{5: 7}$ recombinant inbred lines (RILs) and three 'Thatcher' near-isogenic lines for leaf rust resistance to five races of Puccinia triticina

\begin{tabular}{|c|c|c|c|c|c|c|c|c|c|c|}
\hline \multirow[b]{4}{*}{ Lines $^{c}$} & \multirow{2}{*}{\multicolumn{5}{|c|}{ Infection type ${ }^{a}$}} & \multicolumn{5}{|c|}{ Leaf rust severity $(\%)^{b}$} \\
\hline & & & & & & \multicolumn{5}{|c|}{ Field environment } \\
\hline & \multicolumn{5}{|c|}{ Isolates } & \multirow{2}{*}{$\begin{array}{c}\text { Obregon } \\
2005\end{array}$} & \multirow{2}{*}{$\begin{array}{c}\text { El Batan } \\
2006\end{array}$} & \multirow{2}{*}{$\begin{array}{l}\text { St. Paul } \\
2005\end{array}$} & \multirow{2}{*}{$\begin{array}{c}\text { St. Paul } \\
2006\end{array}$} & \multirow{2}{*}{$\begin{array}{l}\text { Seedling } \\
\text { genes }\end{array}$} \\
\hline & BBBD & THBJ & MHDS & SBDG & PBLR & & & & & \\
\hline Thatcher & $33^{+}$ & 3 & $33^{+}$ & $33^{+}$ & 3 &.$^{\mathrm{d}}$ & $\ldots$ & $40-80$ & $\ldots$ & \\
\hline Jupateco 73S & 0 & 0 & $3^{+}$ & $3^{+}$ & 123 & 100 & 100 & 100 & $50-70$ & $L r 17 a$ \\
\hline Brambling & 123 & $22^{+}$ & $; 1$ & 0 & $; 1^{-}$ & $0-1$ & $0-1$ & $0-1$ & $5-10$ & $\operatorname{Lr} 14 a, \operatorname{Lr} 23$ \\
\hline RL6013 Lr14a & $33^{+}$ & 3 & $3^{+}$ & 0 & $; 1^{-}$ & $\ldots$ & $\ldots$ & $50-70$ & $\ldots$ & \\
\hline RL6008 Lr17a & $; 2+3$ & ;2 & $3^{+}$ & $3^{+}$ & $; 123$ & $\ldots$ & $\ldots$ & $20-70$ & $\ldots$ & \\
\hline RL6012 Lr23 & $; 2+3$ & $2+3$ & 0 & $; 1^{-}$ & $33^{+}$ & $\ldots$ & $\ldots$ & $5-10$ & $\ldots$ & \\
\hline RL6058 Lr34 & $3^{+}$ & $33^{+}$ & $3^{+}$ & $33^{+}$ & $\ldots$ & $\ldots$ & $\ldots$ & $5-10$ & $\ldots$ & \\
\hline RIL117 & $3^{+}$ & $3^{+}$ & $3^{+}$ & 0 & 0 & 100 & 100 & 100 & 90 & $L r 14 a$ \\
\hline RIL128 & $3^{+}$ & $3^{+}$ & $3^{+}$ & $0 ; / 3^{+}$ & $; 123 / 3^{+}$ & 100 & 100 & 100 & 90 & $\begin{array}{l}\text { Lrl } 14 a \\
\text { heterozygous }\end{array}$ \\
\hline RIL105 & 0 & 0 & $3^{+}$ & 3 & 0 & 100 & 100 & 100 & 80 & $\operatorname{Lr} 17 a$ \\
\hline RIL119 & 0 & 0 & $3^{+}$ & $3^{+}$ & 0 & 100 & 100 & 100 & 60 & $\operatorname{Lr} 17 a$ \\
\hline RIL144 & 0 & 0 & $3^{+}$ & $3^{+}$ & 0 & 90 & 100 & 100 & 50 & $\operatorname{Lr} 17 a$ \\
\hline RIL92 & ;123 & $2+3$ & 0 & 0 & $3^{+}$ & 5 & 5 & 10 & 18 & $\operatorname{Lr} 23$ \\
\hline RIL14 & 0 & 0 & $3^{+}$ & 0 & 0 & 100 & 100 & 100 & 60 & $\operatorname{Lr} 17 a, \operatorname{Lr} 14 a$ \\
\hline RIL57 & ;123 & $2+3$ & 0 & 0 & 0 & 100 & 100 & 20 & 15 & $\operatorname{Lr} 23, \operatorname{Lr} 14 a$ \\
\hline RIL104 & $; 123$ & $2+3$ & 0 & 0 & 0 & 100 & 100 & 20 & 15 & $\operatorname{Lr} 23, \operatorname{Lr} 14 a$ \\
\hline RIL93 & 0 & 0 & 0 & 0 & 0 & 100 & 100 & 50 & 20 & $\begin{array}{l}\operatorname{Lr} 17 a, L r 23, \\
(\operatorname{Lr} 14 a ?)^{\mathrm{e}}\end{array}$ \\
\hline RIL113 & 0 & 0 & 0 & 0 & 0 & 100 & 100 & 60 & 30 & $\begin{array}{l}\operatorname{Lr} 17 a, \operatorname{Lr} 23 \\
(\operatorname{Lr} 14 a ?)^{\mathrm{e}}\end{array}$ \\
\hline RIL34 & $3^{+}$ & $3^{+}$ & $3^{+}$ & 3 & $3^{+}$ & 100 & 100 & 100 & 90 & None \\
\hline RIL82 & $3^{+}$ & $3^{+}$ & $3^{+}$ & $3^{+}$ & $3^{+}$ & 100 & 100 & 100 & 90 & None \\
\hline RIL106 & $3^{+}$ & $3^{+}$ & $3^{+}$ & $3^{+}$ & $3^{+}$ & 100 & 90 & 100 & 40 & None \\
\hline
\end{tabular}

a Infection type follows Long and Kolmer (17).

${ }^{\mathrm{b}}$ Leaf rust severity follows Peterson et al. (26).

${ }^{c}$ None of these RILs contain Lr34 according to our csLV34 marker results.

d ... Indicates data not available.

e The presence or absence of Lr14a in the RIL cannot be postulated by the isolates used in this study. 
in each segregating generation in the field nurseries (Fig. 1). However, the disease severity was significantly skewed toward lines with low leaf rust severities. The $\mathrm{F}_{4: 5}$ and $\mathrm{F}_{4: 6}$ lines were considered as the same genotypes. In Mexico, in the $\mathrm{F}_{4: 5}$ and $\mathrm{F}_{4: 6}$ lines, $23 \%$ had 0 to $1 \%$ disease severity, which is similar to Brambling (Fig. 1A). Sixty percent of the lines had average rust severity of 0 to $10 \%$. In the 2005-2006 Mexico environment, $14 \%$ of $\mathrm{F}_{5: 7}$ RILs had disease severity of 0 to $1 \%$ and $64 \%$ of the RILs had average rust severity of 0 to $10 \%$. The same trend was observed in the $\mathrm{F}_{4: 6}$ and $\mathrm{F}_{5: 7}$ RILs grown in St. Paul (Fig. 1B). In St. Paul, $28 \%$ of the $\mathrm{F}_{4: 6}$ RILs and $15 \%$ of the $\mathrm{F}_{5: 7}$ RILs had rust severity of 0 to $5 \%$, in the range of Brambling, and $40 \%$ of the $\mathrm{F}_{4: 6}$ RILs and $30 \%$ of $\mathrm{F}_{5: 7}$ RILs had rust severity of 0 to $10 \%$. The $\mathrm{F}_{1}$ had an average of $5 \%$ rust severity. The skewness toward low rust severity and $F_{1}$ severities suggested that Brambling had APR gene(s) of partial dominance and large effects to reduce rust severity. A chi-squared test was performed using the ratio of lines phenotypically similar to the susceptible parent Jupateco $73 \mathrm{~S}$ and lines with some field resistance. In Mexico, the ratio of number of susceptible lines (100\% leaf rust) to number of lines with some field resistance in $\mathrm{F}_{2: 3}, \mathrm{~F}_{4: 6}$, and $\mathrm{F}_{5: 7}$ fit a three-gene segregation ratio (Table 5). The segregation ratio in $\mathrm{F}_{4: 5}$ fit a two-gene model better than a three-gene model. The high number of susceptible lines in $\mathrm{F}_{4: 5}$ tested in 2003 was likely because of higher than normal temperature in the rust development period in Obregon in 2003. In Mexico, the temperature during rust development period (1 February to 15 March in Obregon and 1 July to 15 August in El Batan) ranged from 9 to $25^{\circ} \mathrm{C}$, with an average of $16^{\circ} \mathrm{C}$. In 2003, the maximum temperature from 1 March to 15 March was above $30^{\circ} \mathrm{C}$. In hot weather, leaf rust infected leaves became necrotic in a short period of time and moderately susceptible plants tend to resemble plants with high terminal disease severity. Nine $\mathrm{F}_{4}$-derived susceptible lines with 100 $\mathrm{S}$ in 2003 were $100 \mathrm{~S}$ in 2004 . The other nine $\mathrm{F}_{4}$-derived lines scored as $100 \mathrm{~S}$ in 2003 had 40 to 90 MSS severity and response in 2004. Those nine lines apparently had gene(s) that were not very effective under high temperature. At the Mexico locations, on the basis of leaf rust severity of $\mathrm{F}_{2: 3}, \mathrm{~F}_{4: 5}, \mathrm{~F}_{4: 6}$, and $\mathrm{F}_{5: 7}$ RILs obtained from 2003-2005, we conclude that leaf rust resistance in Brambling was due to three genes. In St. Paul, the ratio of susceptible lines to lines with some resistance in $\mathrm{F}_{4: 6}$ and $\mathrm{F}_{5: 7}$ fit both three and four independent genes segregation models with a higher probability for four genes (Table 5).

Eight of the nine $\mathrm{F}_{5: 7}$ RILs that scored as $100 \mathrm{~S}$ in 2005 at St. Paul also had $100 \mathrm{~S}$ severity and response in Mexico (Table 3). The other four $\mathrm{F}_{5: 7}$ RILs that were $100 \mathrm{~S}$ in
Mexico, but had lower leaf rust severities in St. Paul, were postulated to carry Lr23 (Table 3). Leaf rust severities of lines that lacked Lr34 in Table 3 indicated that Lr17a and Lr14a were not effective in St. Paul or Mexico. On the basis of the seedling and field results, we concluded that adult-plant leaf rust resistance in Brambling was due to three genes in Mexico, and most likely due to four genes in St. Paul field nurseries. The extra effective gene in St. Paul was likely Lr23.
Since $L r 23$ was effective in St. Paul, the effect of the two APR genes could be studied in lines without Lr23 and Lr34. The correlation coefficient of rust severity of lr23lr23lr34lr34 $\mathrm{F}_{5: 7}$ RILs in 2005 at St. Paul with rust severity of the other environments was higher with the Mexican environments $(r=0.84-0.85$; Table 4) than with the 2006 St. Paul nursery $(r=$ 0.73). In St. Paul, the same leaf rust isolates were used in 2005 and 2006. The lower correlation between the two years in

Table 4. Correlation coefficients for leaf rust severity of $136 \mathrm{~F}_{5: 7}$ recombinant inbred lines (RILs) and a subset of the $\mathrm{F}_{5: 7}$ RILs lacking Lr23 and Lr34 (Ir23lr23lr34lr34) genotype tested in four environments

\begin{tabular}{llccc}
\hline Environment & \multicolumn{1}{c}{ Genotype } & St. Paul 2006 $^{\text {a }}$ & $\begin{array}{c}\text { Obregon, } \\
\text { Mexico }^{\mathbf{a} 2005}\end{array}$ & $\begin{array}{c}\text { El Batan, } \\
\text { Mexico }^{\mathbf{a} 2006}\end{array}$ \\
\hline St. Paul 2005 & All RILs & $0.83^{* * *} \mathrm{c}$ & $0.63^{* * * *}$ & $0.63^{* * *}$ \\
& lr23lr23lr34lr34 & $0.73^{* * *}$ & $0.84^{* * *}$ & $0.85^{* * *}$ \\
St. Paul 2006 & All RILs & & $0.45^{* * * *}$ & $0.45^{* * *}$ \\
& lr23lr23lr34lr34 & & $0.46^{* * *}$ & $0.47^{* * *}$ \\
Obregon 2005 & All RILs & & & $0.99^{* * *}$ \\
& lr23lr23lr34lr34 & & $0.98^{* * *}$ \\
\hline
\end{tabular}

${ }^{a}$ Using mean leaf rust severity of two replications.

${ }^{\mathrm{b}}$ Using leaf rust severity of one replication.

c *** Indicates significant at $P<0.001$.
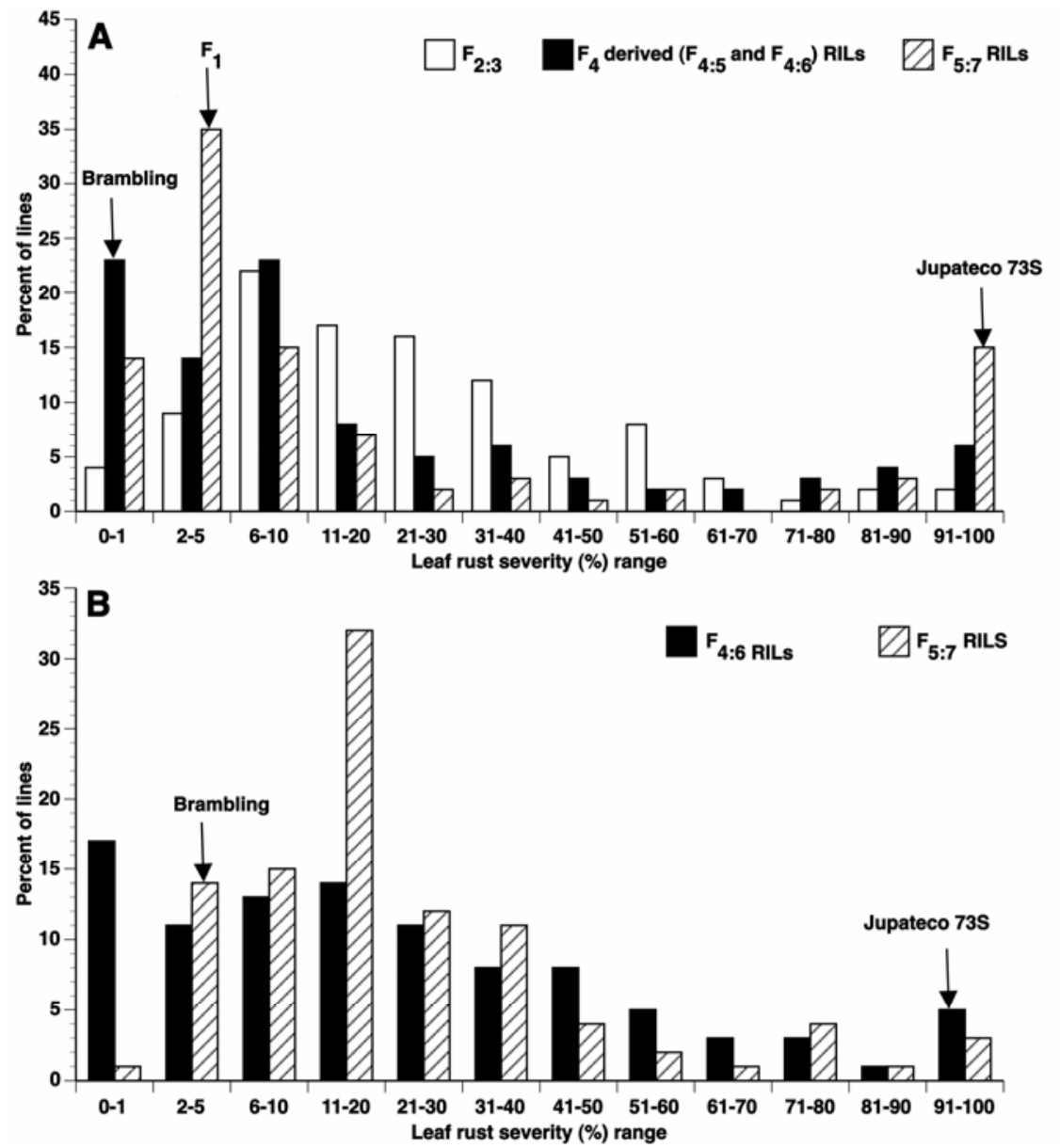

Fig. 1. Frequency distribution of leaf rust severity of $F_{2: 3}$ lines, $F_{4}$-derived $\left(F_{4: 5}\right.$ and $\left.F_{4: 6}\right)$, and $F_{5: 7}$ recombinant inbred lines (RILs) of Jupateco $73 \mathrm{~S} /$ Brambling evaluated in A, Mexico and $\mathbf{B}$, St. Paul, MN. Data of $F_{4}$-derived RILs planted in Mexico were based on means of $F_{4: 5}$ in 2003 and $F_{4: 6}$ in 2004 in Ciudad Obregon. Data of $\mathrm{F}_{5: 7}$ RILs in Mexico were based on means of Ciudad Obregon in 2005 and El Batan in 2006. Data of $F_{5: 7}$ RILs in St. Paul, MN were based on means of 2005 and 2006. 
St. Paul was most likely because of the negative effect of high temperature and dry weather that occurred in 2006. This was also supported by the moderate correlation coefficients between 2006 St. Paul and the two Mexican locations ( $r=0.46,0.47)$.

In Mexico, the $\mathrm{F}_{5: 7}$ RILs without Lr34 displayed continuous distribution of leaf rust severity with most lines skewed toward either of the parents (Fig. 2A). Ten of those 53 lines that lacked Lr34 had a level of resistance similar to Brambling in Mexico (Fig. 2A). The high leaf rust resistance in those lines was most likely due to the combination of the two APR genes. The presence of lines with intermediate low to intermediate high leaf rust severities also indicated that those two genes might have unequal effects in reducing leaf rust severity. In St. Paul, the RILs that lacked Lr23 and Lr34 also displayed a continuous distribution of leaf rust severity (Fig. 2B).

\section{DISCUSSION}

The seedling and adult-plant field rust studies and use of the molecular marker csLV34 allowed us to postulate that $\mathrm{Ju}-$ pateco $73 \mathrm{~S}$ has leaf rust resistance gene Lr17a and Brambling has genes Lr14a, $L r 23, L r 34$, and two unknown APR genes that had an unequal effect on resistance. Using a collection of Mexican leaf rust isolates, Singh and Rajaram (37) postulated that Jupateco $73 \mathrm{~S}$ had $L r 17 a$ and complementary genes $L r 27+L r 31$ (35). The leaf rust isolates used in our seedling study were virulent to $L r 27+L r 31$. Jupateco $73 \mathrm{~S}$ was highly susceptible at both field sites in Mexico where race MCJ/SP was used to initiate rust epidemics. It was also susceptible to a mixture of isolates used at St. Paul, MN nurseries. Thus, $L r 17 a$ and $L r 27+L r 31$ in Jupateco $73 \mathrm{~S}$ were not effective against the isolates used in Mexico and St. Paul. Gene Lr14a identi- fied in Brambling also was not effective against races in our field studies.

The near-immune level of APR in Brambling was due to the combination of slow- rusting gene Lr34 with two other APR genes at both Mexico and St. Paul with additional resistance conditioned by $\operatorname{Lr} 23$ at St. Paul only. The APR genes in Bram-
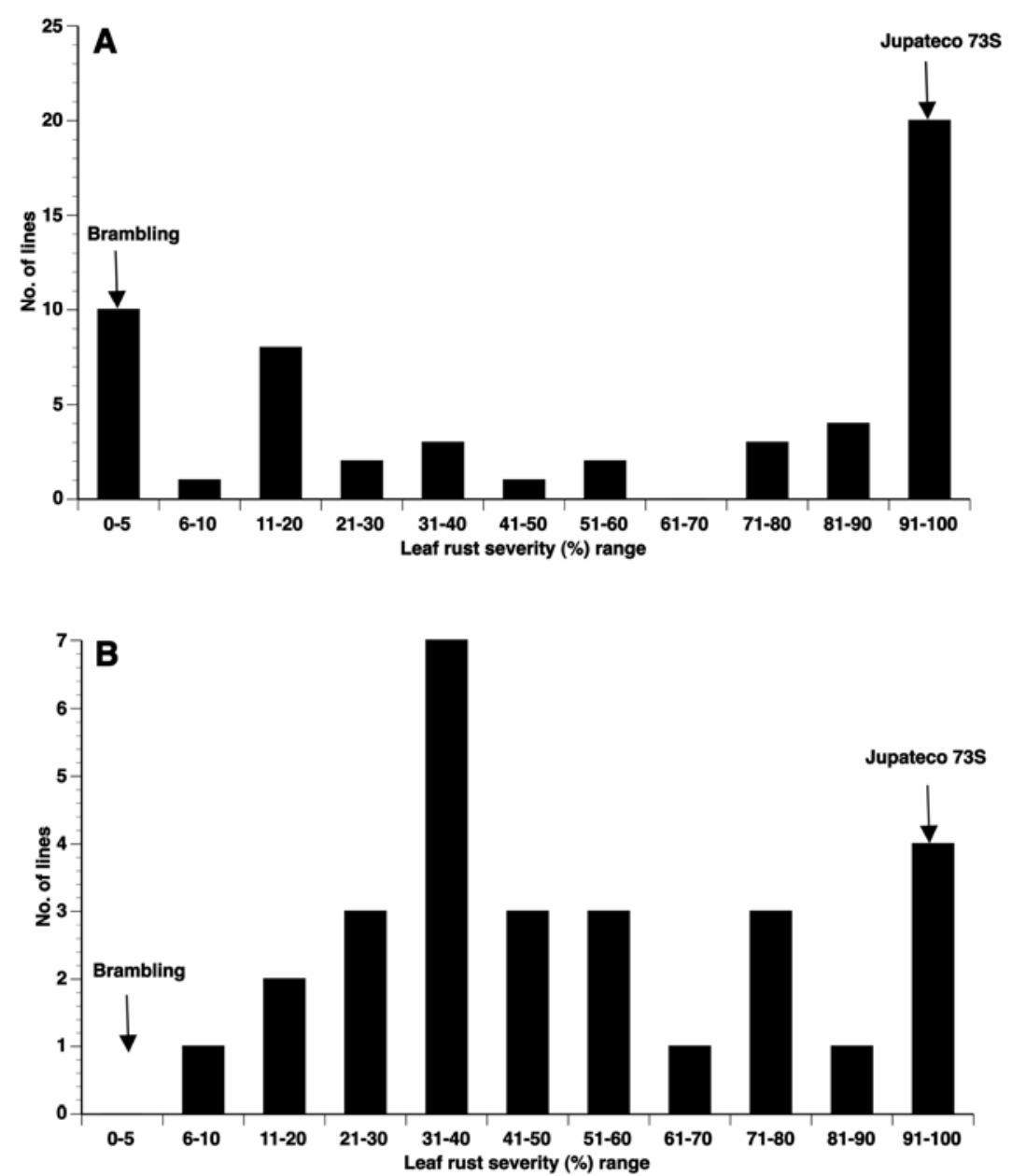

Fig. 2. Distribution of adult-plant leaf rust severity of $54 \mathrm{~F}_{5: 7}$ lines lacking $\operatorname{Lr} 34$ evaluated in A, Mexico and 28 lines lacking Lr23 and Lr34 evaluated in B, St. Paul, MN. Mexico data was based on means of Ciudad Obregon in 2005 and El Batan in 2006. The St. Paul data was based on means of field trials in 2005 and 2006.

Table 5. Distribution and chi-square test of $F_{2: 3}$ to $F_{5: 7}$ generations of 'Jupateco 73S/Brambling' cross evaluated in seven field environments

\begin{tabular}{|c|c|c|c|c|c|c|}
\hline \multirow[b]{2}{*}{ Environment } & \multirow[b]{2}{*}{ Generation } & \multicolumn{2}{|c|}{ No. of lines } & \multirow[b]{2}{*}{ Estimated gene number ${ }^{\mathrm{a}}$} & \multirow[b]{2}{*}{$\chi^{2}$ value } & \multirow[b]{2}{*}{$P$ value } \\
\hline & & Susceptible & Others & & & \\
\hline \multicolumn{7}{|l|}{ Mexico } \\
\hline Obregon 2003 & $\mathrm{~F}_{2: 3}$ & 5 & 232 & 3 & 0.46 & 0.50 \\
\hline \multirow[t]{3}{*}{ Obregon 2003} & $\mathrm{~F}_{4: 5}$ & 18 & 115 & 2 & 2.70 & 0.10 \\
\hline & & & & 3 & 4.62 & 0.03 \\
\hline & & & & 4 & 36.77 & $<0.01$ \\
\hline \multirow[t]{2}{*}{ Obregon 2004} & $\mathrm{~F}_{4: 6}$ & 9 & 137 & 3 & 0.93 & 0.34 \\
\hline & & & & 4 & 31.39 & $<0.01$ \\
\hline \multirow[t]{2}{*}{ Obregon 2005} & $\mathrm{~F}_{5: 7}$ & 13 & 122 & 3 & 0.03 & 0.86 \\
\hline & & & & 4 & 7.19 & 0.01 \\
\hline \multirow[t]{2}{*}{ El Batan 2006} & $\mathrm{~F}_{5: 7}$ & 13 & 122 & 3 & 0.03 & 0.86 \\
\hline & & & & 4 & 7.19 & $0.01 \mathrm{~s}$ \\
\hline \multicolumn{7}{|l|}{ St. Paul, MN } \\
\hline \multirow[t]{2}{*}{2004} & $\mathrm{~F}_{4: 6}$ & 7 & 139 & 3 & 2.43 & 0.12 \\
\hline & & & & 4 & 0.53 & 0.47 \\
\hline \multirow[t]{2}{*}{2005} & $\mathrm{~F}_{5: 7}$ & 9 & 127 & 3 & 2.51 & 0.11 \\
\hline & & & & 4 & 1.04 & 0.31 \\
\hline \multirow[t]{2}{*}{2006} & $\mathrm{~F}_{5: 7}$ & 7 & 123 & 3 & 3.18 & 0.07 \\
\hline & & & & 4 & 0.13 & 0.72 \\
\hline
\end{tabular}

${ }^{a}$ The ratio used for $\mathrm{F}_{2: 3}$ was 1 susceptible: 63 others for three genes. The ratios used in $\mathrm{F}_{4: 5}$ and $\mathrm{F}_{4: 6}$ were 0.1914 susceptible:0.8086 others for two genes, 0.0837 susceptible:0.9163 others for three genes, and 0.0366 susceptible:0.9634 others for four genes. The ratios used in $\mathrm{F}_{5: 7}$ were 0.101 susceptible:0.899 others for three genes and 0.0473 susceptible:0.9527 others for four genes. 
bling had dominant or strong partial dominant effects. The Thatcher lines with $L r 23$ had moderate levels of leaf rust resistance in field plots at St. Paul. Our results indicated that, when effective, gene $L r 23$ interacted with the APR gene Lr34 and provided higher levels of APR than when those genes acted alone. When ineffective against corresponding virulent races, Lr23 failed to interact with $\operatorname{Lr} 34$. Thus, there was not a residual effect of gene $L r 23$. A similar example of interaction where $\operatorname{Lr} 34$ enhances the effect of Lrl3 and other adult-plant race-specific leaf rust resistance genes was reported earlier $(7,8,10)$. In Mexico, when tested against races virulent to Lrl3 in the field, Lrl3 did not enhance the resistance of $L r 34$ (30). $L r 23$ is a common gene in U.S. spring wheat cultivars $(13,24)$. Spring wheat cultivars with the combination of $\operatorname{Lr} 16, \operatorname{Lr} 23$, and $L r 34$ have displayed high levels of leaf rust resistance in the United States (13). In our study, the differential expression of $L r 23$ in Mexico and St Paul was mainly due to the race specificity of $L r 23$ rather than temperature sensitivity. The resistance gene Lr23 was not effective against the race used in Mexico at the seedling stage and at the adult-plant stage in Mexican field nurseries and in controlled environment at a high temperature (R. P. Singh, unpublished data). Lr23 was effective against one of the isolates (THBJ) used in St. Paul, MN.

Lr34 reduced leaf rust severities more in Mexico than in St. Paul, MN. The resistance conditioned by $\operatorname{Lr} 34$ was in accordance with previous studies of 20 to $60 \%$ reduction in leaf rust severity $(20,32)$. The different effects of Lr34 in Mexico and St. Paul were possibly due to the temperature sensitivity of this gene. Lr34 is reported to condition more resistance at low temperatures than at high temperatures $(6,33)$. Compared with Mexican locations, the rust development period at St. Paul was much shorter and the daily temperature rose at a faster rate (daily temperature 16 to $20^{\circ} \mathrm{C}$, average $22^{\circ} \mathrm{C}$ ). The resistance of lines with Lr34 in 2005 was typical of this gene at St. Paul and the rest of the U.S. spring wheat region (23). The higher rust severities on lines with Lr34 in 2006 compared with 2005 at St. Paul was due to the abnormally hot, dry weather in 2006.

In Obregon, the $F_{1}$ of Brambling/Jupateco $73 \mathrm{~S}$ had much lower disease severity than the mid parent value. The two APR genes combined with Lr34 skewed the segregation of progeny toward Brambling phenotype. Similar levels of rust in the $F_{1}$ because of partial dominance of slow-rusting genes were reported in genetic studies of lines carrying three to four slow-rusting genes (22,30). However, the frequency of homozygous parental type resistance and homozygous parental type of susceptible lines in segregating generations in those studies were proportional according to an additive gene model.
Previous studies indicated that lines with two slow-rusting genes had approximately 5 to $30 \%$ leaf rust severity $(9,36)$, and immune levels of resistance was reached by combining three to four genes $(22,30,31)$. This is the first report that the combination of the two slow-rusting genes other than Lr34 had immune levels of resistance in the Mexico environments. Further quantitative trait loci (QTL) analysis should provide the chromosome location of these genes in Brambling.

Differential expression due to race specificity of gene $L r 23$ was one of the main factors causing genotype $\times$ environment interaction between Mexico and St. Paul. Temperature differences might be another factor that caused genotype $\times$ environment interaction between St. Paul and Mexico. Pyramiding slow-rusting resistance genes can achieve stable high levels of resistance. The dominant nature of some of the slow-rusting resistance genes in Brambling are of great interest in breeding for durable rust resistance. This type of resistance will be easier to select for in segregating generations as smaller population sizes would be required than when using lesser effects.

\section{ACKNOWLEDGMENTS}

We thank Jackie Rudd, Texas Agricultural Experiment Station, Texas A\&M University for his support of this research at the early stage of the population development.

\section{LITERATURE CITED}

1. Bassam, B. J., Caetanoanolles, G., and Gresshoff, P. M. 1991. Fast and sensitive silver staining of DNA in polyacrylamide gels. Anal. Biochem. 196:80-83.

2. Caldwell, R. M. 1968. Breeding for general and/or specific plant disease resistance. Pages 263-272 in: 3rd Int. Wheat Genet. Symp. W. Finlay and K. W. Shepherd, eds. Aust. Acad. Sci., Canberra, Australia.

3. Chester, K. S. 1946. The Nature and Prevention of the Cereal Rusts as Exemplified in the Leaf Rust of Wheat. Chronica Botanica Co, Waltham, MA

4. Dyck, P. L. 1987. The association of a gene for leaf rust resistance with the chromosome 7D suppressor of stem rust resistance in common wheat. Genome 29:467-469.

5. Dyck, P. L., and Johnson, L. 1983. Temperature sensitivity of genes for resistance in wheat to Puccinia recondita. Can. J. Plant Pathol. 5:229-234.

6. Dyck, P. L., and Samborski, D. J. 1982. The inheritance of resistance to Puccinia recondita in a group of common wheat cultivars. Can. J. Genet. Cytol. 24:273-283.

7. Ezzahiri, B., and Roelfs, A. P. 1989. Inheritance and expression of adult-plant resistance to leaf rust in Era wheat. Plant Dis. 73:549551.

8. German, S. E., and Kolmer, J. A. 1992. Effect of gene Lr34 in the enhancement of resistance to leaf rust of wheat. Theor. Appl. Genet. 84:97-105.

9. Khanna, R., Bansal, U. K., and Saini, R. G. 2005. Genetics of durable resistance to leaf rust and stripe rust of an Indian wheat cultivar HD2009. J. Appl. Genet. 46:259-263.

10. Kolmer, J. A. 1992. Enhanced leaf rust resistance in wheat conditioned by resistance gene pairs with Lr13. Euphytica 61:123-130.

11. Kolmer, J. A. 2001. Physiologic specialization of Puccinia triticina in Canada in 1998. Plant Dis. 85:155-158.

12. Kolmer, J. A., Long, D. L., and Hughes, M. E. 2005. Physiologic specialization of Puccinia triticina on wheat in the United States in 2003. Plant Dis. 89:1201-1206.

13. Kolmer, J., and Oelke, L. M. 2006. Genetics of leaf rust resistance in the spring wheats 'Ivan' and 'Knudson'. Can. J. Plant Pathol. 28:1-9.

14. Lagudah, E. S., McFadden, H., Singh, R. P., Huerta-Espino, J., and Spielmeyer, W. 2006 Molecular genetic characterization of the Lr34/Yr18 slow-rusting resistance gene region in wheat. Theor. Appl. Genet. 114:21-30.

15. Litt, M., Hauge, X., and Sharma, V. 1993. Shadow bands seen when typing polymorphic dinucleotide repeats: Some causes and cures. Biotechniques 15:280-284.

16. Liu, S., Zhang, X., Pumphrey, M. O., Stack, R. W., Gill, B. S., and Anderson, J. A. 2006 Complex microcolinearity among wheat, rice, and barley revealed by fine mapping of the genomic region harboring a major QTL for resistance to Fusarium head blight in wheat. Funct. Integr. Genomics 6:83-89.

17. Long, D. L., and Kolmer, J. A. 1989. A North American system of nomenclature for Puccinia recondita f. sp. tritici. Phytopathology 79:525-529.

18. Long, D. L., Leonard, K. J., and Roberts, J. J. 1998. Virulence and diversity of wheat leaf rust in the United States in 1993 to 1995. Plant Dis. 82:1391-1400.

19. Martinez, F., Niks, R. E., Singh, R. P., and Rubiales, D. 2001. Characterization of Lr46, a gene conferring partial resistance to wheat leaf rust. Hereditas 135:111-114.

20. McIntosh, R. A. 1992. Pre-emptive breeding to control wheat rusts. Euphytica 63:103-113.

21. McIntosh, R. A., Hart, G. E., Devos, K. M., Morris, C. F., and Rogers, W. J. 2003. Catalogue of gene symbols for wheat. Ann. Wheat Newsl. 49:246-282.

22. Navabi, A., Singh, R. P., Tewari, J. P., and Briggs, K. G. 2003. Genetic analysis of adultplant resistance to leaf rust in five spring wheat genotypes. Plant Dis. 87:1522-1529.

23. Oelke, L. M., and Kolmer, J. A. 2004. Characterization of leaf rust resistance in hard red spring wheat cultivars. Plant Dis. 88:11271133 .

24. Oelke, L. M., and Kolmer, J. A. 2005. Genetics of leaf rust resistance in spring wheat cultivars Alsen and Norm. Phytopathology 95:773-778.

25. Parlevliet, J. E. 1988. Strategies for the utilization of partial resistance for the control of cereal rusts. Pages 48-62 in: Breeding Strategies for Resistance to the Rusts of Wheat. N. W. Simmonds and S. Rajaram, eds. CIMMYT, Mexico, D. F.

26. Peterson, R. F., Campbell, A. B., and Hannah, A. E. 1948. A diagrammatic scale for estimating rust intensity on leaves and stems of cereals. Can. J. Res. 26:496-500.

27. Samborski, D. J. 1985. Wheat leaf rust. Pages 39-59 in: The Cereal Rusts. A. P. Roelfs and W. R. Bushnell, eds. Academic Press, Orlando, FL.

28. Singh, R. P. 1991. Pathogenicity variations of Puccinia recondita f. sp. tritici and $P$. graminis f. sp. tritici in wheat-growing areas of Mexico during 1988 and 1989. Plant Dis. 75:790-794.

29. Singh R. P. 1992. Genetic association of leaf rust resistance gene $\operatorname{Lr} 34$ with adult-plant resistance to stripe rust in bread wheat. Phytopathology 82:835-838.

30. Singh, R. P. 1992. Genetics of adult plant resistance of leaf rust in 'Frontana' and three CIMMYT wheats. Genome 35:24-31.

31. Singh, R. P. 1994. Genetics of adult plant resistance to strip rust in ten spring bread wheats. Euphytica 72:1-7.

32. Singh, R. P., and Gupta, A. K. 1992. Expression of wheat leaf rust resistance gene $\operatorname{Lr} 34$ in 
seedlings and adult plants. Plant Dis. 76:489491.

33. Singh, R. P., and Huerta-Espino, J. 2003. Effect of leaf rust resistance gene $L r 34$ on components of slow-rusting at seven growth stages in wheat. Euphytica 129:371-376.

34. Singh, R. P., Huerta-Espino, J., and Rajaram, S. 2000. Achieving near-immunity to leaf and stripe rusts in wheat by combining slow-rusting resistance genes. Acta Phytopathol. Entomol. Hung. 35:133-139.

35. Singh, R. P., and McIntosh, R. A. 1984. Complementary genes for reaction to Puccinia recondita tritici in Triticum aestivum I. Genetic and linkage studies. Can. J. Genet. Cytol. 26:723-735.
36. Singh, R. P., Mujeeb-Kazi, A., and HuertaEspino, J. 1998. Lr46: A gene conferring slowrusting resistance to leaf rust in wheat. Phytopathology 88:890-894.

37. Singh, R. P., and Rajaram, S. 1991. Resistance to Puccinia recondita f. sp. tritici in 50 Mexican bread wheat cultivars. Crop Sci. 31:1472-1479. 